\title{
Desirable System Requirements for Employee Performance Evaluation to Establishment of Meritocracy and Continuous Improvement by using TQMPE and AHP Model
}

\author{
Hassan Rangriz and Hooman Pashootanizadeh*
}

Department of Management, University of Economic Sciences, Tehran, Iran

\begin{tabular}{|c|c|}
\hline Abstract & Article Information \\
\hline $\begin{array}{l}\text { The present work attempts to develop a multidimensional performance evaluation } \\
\text { framework of development projects by considering all relevant measures of performance. } \\
\text { In order to demonstrate the applicability of this performance evaluation framework, it has } \\
\text { considered the case of private and state-owned bank projects constructed between } 2010 \\
\text { and } 2014 \text { in Iran and collected the viewpoints of } 447 \text { respondents. The investigation of } \\
\text { performance evaluation is one of the main issues in the human management resource } \\
\text { (HRM) and many empirical studies have been concentrated to this field. For this purpose, } \\
\text { the main objective of this study is to investigate the staff performance evaluation in } \\
\text { private and state-owned banks in Iran by using on TQMPE and AHP models. } \\
\text { Copyright@2014 STAR Journal. All Rights Reserved. }\end{array}$ & $\begin{array}{l}\text { Article History: } \\
\text { Received : 09-06-2014 } \\
\text { Revised : 17-09-2014 } \\
\text { Accepted : 25-09-2014 } \\
\text { Keywords: } \\
\text { Performance evaluation } \\
\text { Meritocratic system systematic } \\
\text { thinking } \\
\text { Training and development } \\
{ }^{*} \text { Corresponding Author: } \\
\text { Hooman Pashootanizadeh } \\
\text { E-mail: } \\
\text { pashotany@yahoo.com }\end{array}$ \\
\hline
\end{tabular}

\section{INTRODUCTION}

Human resources with knowledge and competencies are the key assets in assisting organizations to sustain their competitive advantage. Globally competitive organizations depend on the uniqueness of their human resources and the systems for managing human resources effectively to gain competitive advantages. Performance evaluation of the human resources is a vital issue in this regard. In creating and implementing an appraisal system, management must determine what the performance appraisal (PA) system will be used for and then decide on the process to implement the system. The methods chosen and the instruments used to implement these methods are crucial in determining whether the organization manages its performance successfully.

Development projects play a key role in the growth of economies in developing countries in terms of their contribution towards Gross Domestic Product (GDP), employment generation and provision of an important market for materials and products produced by other sectors of the economy (ILO, 2001). The unique features of a development project in terms of its ability to create economic wealth, deliver social welfare services and at the same time its possibility to create negative environmental impact suggest that this kind of a project needs to be evaluated on economic as well as social and environmental dimensions. However, these projects have mostly been evaluated on the criteria of cost, time and quality, as revealed in literature (Ahadzie et al., 2008; Atkinson, 1999; Chan et al., 2002; Salleh, 2009).
Academic researchers with a view to overcoming the limitations of the traditional performance evaluation criteria of time, cost and quality have suggested the inclusion of additional measures of performance. These include safety of the project site (Billy et al., 2006; Haslam et al., 2005; Ortega, 2000), site disputes (Tabish and Jha, 2011), environmental impact (Eriksson and Westerberg, 2011) and community/client/customer satisfaction (Ali and Rahmat, 2010; Chan and Chan, 2004; CURT, 2005). These contributions, although widen the scope of performance evaluation amongst development projects, are skewed towards either societal or environmental aspects.

Majority of the researchers associated with construction project management have talked about the importance of time, cost and quality (Ahadzie et al., 2008; Kaliba et al., 2009; Kamrul and Indra, 2010; Zuo et al., 2007) while evaluating the performance of public or private construction projects. The use of these three metrics can be traced back to the inception of project management concept in 1950s. As early as in 1989, Kerzner reported that project management has been traditionally described as managing or controlling company resources on a given activity within time, cost and performance (Kerzner, 2006). This conventional criterion has been hailed for having provided a basis in evaluating the extent of success across projects (Cao and Hoffman, 2011), being simple (Toor and Ogunlana, 2006), being easy and timely to measure (Willard, 2005) and its ability to capture the tangible benefits of the projects (Litsikakis, 2009). 


\section{Hassan Rangriz and Hooman Pashootanizadeh}

The importance of performance evaluation of personnel and its relationship to the firm's performance is well documented in the literature (Lowe, 1986; Katzenbach and Smith, 1993; Kilduff et al., 2000; Higgs, 2005). A variety of appraisal techniques are available to measure performance (Chang and Hahn, 2006; Jiang et al., 2001; Armentrout, 1986; Arvey and Murphy, 1998; Sanchez and De La Torre, 1996; Stronge, 1991). Klein et al. (1993) proposed a model for PA interview adapted from open systems theory.

As modern organizations seek flexibility in response to the exponential growth in technology and globalisation, they view greater employee participation in decision making (PDM) as a means of gaining more from an educated, technologically oriented workforce (Connell, 1998). Some researchers claim employee involvement has motivational effects of increased employee job satisfaction and organizational commitment (Guthrie, 2001; Latham et al., 1994; Pearson and Duffy, 1999; Witt et al., 2000); however, others claim the support is inconclusive (Jones, 1997; Scully et al., 1995; Tjosvold, 1998).

Personnel performance evaluations are critical to an organization's control system (Burkert, Fischer, and Schaeffer, 2011). Performance Review systems provide support for pay increases, bonuses, and promotions as well as help in identifying practices to emulate and those to remediate. In response to dissatisfaction with traditional systems emphasizing short-term financial targets, many companies have adopted performance measurement systems that employ multiple lead and lag measures of performance (e.g., customer related goals, infrastructure goals, learning and innovation goals; see Wiersma, 2009). By doing so, the performance measurement system directs attention to and demands accountability in areas beyond a narrow short-term financial perspective (Bartlett, Johnson, and Reckers, 2014). In this respect, Ferreira and Otley (2009) call for further research on more complex and comprehensive settings, which would expand the observation of measures that are absent or limited in scope.

\section{MATERIALS AND METHODS}

\section{Participation in Decision Making}

When employees believe in and trust their management, it motivates and encourages employees' participation in decision making which improves employees' efforts, and benefits their job satisfaction and commitment to work. All of these factors, in turn, contribute to a trustworthy manager-employee relationship. While the literature supports this premise, there is little empirical evidence that patterns of causal inference in the relationship are clearly understood. This three-part empirical case aims to focus on studying the relations between employee trust in management in a Quebec manufacturing company and their job satisfaction, intention to quit, level of employee participation in decision making and their commitment.

Insufficient employee participation in decision making in turn leads to low level of employee job satisfaction and employee commitment. Lack of employee commitment and engagement affects the employee's intention to quit.

\section{Commitment and Job Satisfaction}

Job satisfaction has been found to be closely related to life satisfaction (see Judge and Watanabe (1993)). The
Sci. Technol. Arts Res. J., July-Sep 2014, 3(3): 185-190

economics literature on job satisfaction was started by Freeman (1978) and Borjas (1979). Freeman found job satisfaction to be a major determinant of labor market mobility and found it to be dependent on union membership. These results were consistent with those of Borjas who also found that while union members were less satisfied, the magnitude of the effect was stronger at higher tenure levels. Phelps (1968) described the relationship between job satisfaction and quit behavior.

One of the most researched areas in the field of human resource management (HRM) is the effects of job satisfaction on employees' performance (Judge, Thoresen, Bono, and Patton, 2001). Research linking employees' performance with satisfaction and other attitudes has been studied since at least 1939, with the Hawthorne studies (Roethlisberger and Dickson, 1939). In Judge et al. (2001), it was found by Brayfield and Crockett (1955) that there is only a minimal the effects of job satisfaction on employees' performance. However, since 1955, Judge et al. (2001) cited that there are other studies by Locke (1970), Schwab and Cummings (1970), and Vroom (1964) that have shown that there is at least some relationship between those variables. laffaldano and Muchinsky (1985) did an extensive analysis on the effects of job satisfaction on employees' performance. There are also stronger relationships depending on specific circumstances such as mood and employee level within the company (Morrison, 1997). Organ (1988) also found that the employees' performance and job satisfaction relationship follows the social exchange theory; employees' performance is giving back to the organization from which they get their satisfaction.

Judge et al. (2001) argued that there are seven different models that can be used to describe the job satisfaction and employees' performance relationship. Some of these models view the effects of job satisfaction on employees' performance to be unidirectional, that either job satisfaction causes employees' performance or vice versa. Another model states that the relationship is a reciprocal one; this has been supported by the research of Wanous (1974). The underlying theory of this reciprocal model is that if the satisfaction is extrinsic, then satisfaction leads to employees' performance, but if the satisfaction is intrinsic, then the employees' performance leads to satisfaction. Other models suggest there is either an outside factor that causes a seemingly relationship between the factors or that there is no relationship at all, however, neither of these models have much research.

Job satisfied employees are more likely to accept the organisation's goals and put in greater work effort to positively influence organizational outcomes (Ostroff, 1992). Participation enhances acceptance, which positively influences satisfaction (Black and Gregersen, 1997; Locke and Schweiger, 1979; Miller and Monge, 1986) and reduces stress, uncertainty and ambiguity (Daniels and Bailey, 1999). Job satisfaction measures the individuals liking for their job (Brooke et al., 1988; Judge, 1993) and their attitudinal response to the rewards provided (Lawler and Hall, 1970; Locke, 1976). While individual traits and perceptions also influence satisfaction levels, they tend to be constant over time (Judge and Watanabe, 1993); therefore, organizations are better off addressing internal factors, such as the work climate (Payne and Pugh, 1976), commitment foci (Becker and Billings, 1993; Becker et al., 1996) and PDM (Miller and Monge, 1986) when seeking to change satisfaction levels 


\section{Hassan Rangriz and Hooman Pashootanizadeh}

over time. These contextual issues become even more important when employees have to deal with uncertainty, such as is occurring in the current environment where jobs are being restructured or lost (Blau, 1999).

The correlation between job satisfaction and commitment has been well expounded in the literature (Allen and Meyer, 1990; Becker and Billings, 1993; Becker et al., 1996; Meyer, 1997; Wright, 1997). Mowday et al. (1982, p. 27) define commitment as the strength of employees' "identification with and involvement in the organisation". Acknowledging commitment can extend to other foci such as supervisors (Benkhoff, 1997), work environment (Roy and Ghose, 1997) occupation or profession (Meyer et al., 1993; Pearson and Duffy, 1999), career or work ethic (Cohen, 1996), this study focuses on organizational commitment.

Allen and Meyer (1990) have identified three types of commitment, these being affective, continuance and normative commitment. The motivation for each type of commitment has different implications. Affective commitment refers to the individuals' emotional attachment to the organisation. Continuance commitment occurs when individuals remain with an organisation because the cost of leaving outweighs the cost of staying; whereas, normative commitment occurs when individuals retain membership out of obligation. Previous researchers have identified that affective commitment offers the most positive organisational outcomes in terms of performance (Allen and Meyer, 1990; Brooke et al., 1988) reduced turnover and absenteeism and improved job satisfaction (Allen and Meyer, 1990; Judge, 1993). For this reason, only affective commitment was measured in this study.

\section{Performance Evaluation}

Performance evaluation is central to management control systems, and has been shown to influence managerial behavior and performance (Feltham and Xie, 1994; Murphy and Cleveland, 1995; Otley, 1999). This influence depends on the properties of the performance measures and the fairness of the procedures used for the performance evaluation (Boland Smith, 2011; Giraud, Langevin, and Mendoza, 2008; Greenberg, 1986; Hartman and Slapnicar, 2012).

The general characterization is that outcome based contracts can be effectively used to motivate effort and control performance. Accounting data traditionally has served to measure performance, and considerable research has focused on identifying those performance measures most effective under different conditions. Performance evaluation has been characterized as an objective comparison of actual performance on selected performance measures with expected performance. Consequently, the potential sources of distortion in performance evaluation constitute an important continuing focus of research. Sub-optimal performance evaluation implementations are those in which a superior considers information other than that identified in performance contracts (Kunda, 1990; Varma et al., 1996).

Performance evaluation is an assessment model to compare past plans and executions of strategies, operating activities and target establishment of organizations with executive abilities, participating rate and competing rate of employees. Furthermore, this assessment model is helping organizations to plan future
Sci. Technol. Arts Res. J., July-Sep 2014, 3(3): 185-190

strategies and set up performance targets of employees in order to achieve the final target of the entire organizations. Green and Keim (1983) stated that "Performance evaluation is for achieving the entire target. It bases on the quantification standard made in advance or using subjective judgment to assess the result of daily operation; in the meanwhile, performance evaluation also possesses the function of amending responding policies and unifying the target of individuals and organizations.

\section{Procedural Justice in Performance Evaluation}

Procedural justice was transferred to business organizations by Leventhal (1980), who identified six criteria of perceived procedural justice.6 According to these criteria, subsequent research has shown that performance evaluation is most likely to be perceived as fair when evaluees have access to detailed information about the performance measures used and perceive them as highly relevant, and when the performance evaluation is conducted uniformly and without bias among subordinates (Greenberg, 1986; McFarlinand Sweeny, 1992; Prendergast and Topel, 1996). Despite the influence of procedural justice on the effectiveness of control mechanisms, the management accounting research, with a few exceptions (Hartmann andSlapnicar, 2012; Mass et al., 2012; Lau and Moser, 2008), has largely ignored the conditions that bring performance evaluation procedures more or less in line with the principles of procedural justice.

Baker et al. (1994) agency-based model proposes that an employee's contribution to firm value cannot be completely measured by objective measures, and that superiors who are well placed to observe subtleties of employee behavior can perform a subjective evaluation to complement these measures. Moreover, at managerial levels, where jobs are complex, subjectivity in performance evaluation can therefore complement the available objective measures and improve incentive contracting (Bol, 2008; Gibbs et al., 2004). Thus, incorporating subjectivity into performance evaluation can benefit both firms and managers. Subjectivity enables superiors to use non-quantifiable and other relevant information that emerges during the evaluation period, reducing incentive costs for firms and incentive risks for managers (Gibbs et al., 2004; Ittner et al., 2003; Prendergast and Topel, 1996).

However, studies also suggest that subjectivity in performance evaluation is effective only if the superior makes fair, unbiased judgements, and if the subordinate does not try to inappropriately influence the superior's assessment.

\section{Planning Training and Development Requirements}

Security-oriented programs require different types of training for various purposes. In most organizations, entrylevel training receives the greatest attention. This is a reasonable policy. However, programs cannot become static. Training programs require periodic review and renewal so that programmatic content remains fresh and pertinent. Changes in the workplace and society make good training and development important. Many executives think of training as a cost burden. However, the training process should provide precise, desired results for management, with measurable changes in work place. 
Hassan Rangriz and Hooman Pashootanizadeh

RESULTS AND DISCUSSION

Descriptive Statistics

Table 1: The reliability of test results

\begin{tabular}{|c|c|c|}
\hline $\begin{array}{l}\text { The Number of } \\
\text { Sub Criteria }\end{array}$ & $\begin{array}{c}\text { Value of } \\
\text { Test statistic }\end{array}$ & $\begin{array}{c}\alpha \text { for each } \\
\text { TQMPE Criteria }\end{array}$ \\
\hline 6 & 0.821 & $\begin{array}{l}\alpha \text { for the first criteria } \\
\text { (Focus on Customers) }\end{array}$ \\
\hline 6 & 0.812 & $\begin{array}{l}\alpha \text { for the second criteria } \\
\text { (Improvement) }\end{array}$ \\
\hline 6 & 0.851 & $\begin{array}{l}\alpha \text { for the third criteria } \\
\text { (Teamwork) }\end{array}$ \\
\hline 6 & 0.841 & $\begin{array}{l}\alpha \text { for the fourth criteria } \\
\text { (Management) }\end{array}$ \\
\hline 6 & 0.872 & $\begin{array}{l}\alpha \text { for the fifth criteria } \\
\text { (Procedure Thinking) }\end{array}$ \\
\hline 6 & 0.805 & $\begin{array}{l}\alpha \text { for the sixth criteria } \\
\text { (Systematic thinking) }\end{array}$ \\
\hline 6 & 0.853 & $\begin{array}{l}\alpha \text { for the seventh criteria } \\
\text { (Decision Making) }\end{array}$ \\
\hline 2 & 0.648 & $\begin{array}{l}\alpha \text { for the eighth criteria } \\
\text { (Bilateral relation) }\end{array}$ \\
\hline 44 & 0.966 & $\alpha$ for the questionnaire \\
\hline
\end{tabular}

Table 2: Calculation significance the first criteria (Focus on customers)

\begin{tabular}{ccl}
\hline Ranking & Significance & \multicolumn{1}{c}{ Sub Criteria } \\
\hline 2 & 0.277 & Responsibility \\
3 & 0.165 & Appropriate relationship with \\
6 & 0.039 & Austomers and employees \\
4 & 0.0691 & Attention to customers complaint \\
1 & 0.402 & Privacy Policy \\
5 & 0.0476 & Dominate the electronic media \\
\hline
\end{tabular}

The above results in table 2 are shown, privacy policy between all sub criteria in the first criteria (Focus on customers) is more important than others, and attention to customer's complaint is less important than other sub criteria.

Table 2.1: Compatibility rate for the first criteria

\begin{tabular}{cc}
\hline The number of sub criteria & CR \\
\hline 6 & 0.079 \\
\hline
\end{tabular}

According to the above results, the compatibility rate is equal 0.079 , which is less than 0.1 , then compatibility between six sub criteria in first criteria (Focus on customers) has been accepted.

Table 3: Calculation significance the second criteria (Improvement)

\begin{tabular}{ccl}
\hline Ranking & significance & \multicolumn{1}{c}{ sub criteria } \\
\hline 1 & 0.422 & Increased knowledge and job skills \\
6 & 0.029 & Attend meetings \\
3 & 0.147 & The ability to analyze \\
2 & 0.251 & Effort to learn \\
4 & 0.098 & Creativity \\
5 & 0.0621 & Ability to transfer information \\
& & and work experience \\
\hline
\end{tabular}

The above results in table 3 are shown, increased knowledge and job skills between all sub criteria in the second criteria (Improvement) is more important than others, and attend meeting is less important than other sub criteria.
Sci. Technol. Arts Res. J., July-Sep 2014, 3(3): 185-190

Table 3.1: Compatibility rate for the second criteria

\begin{tabular}{cc}
\hline The number of sub criteria & CR \\
\hline 6 & 0.081 \\
\hline
\end{tabular}

According to the above results, the compatibility rate is equal 0.081 , which is less than 0.1 , then compatibility between six sub criteria in second criteria (Improvement) has been accepted.

Table 4: Calculation significance the third criteria (Teamwork)

\begin{tabular}{|c|c|c|}
\hline Ranking & Significance & Sub criteria \\
\hline 1 & 0.430 & Cooperation and partnership \\
\hline 6 & 0.037 & Interest to membership in groups \\
\hline 3 & 0.118 & $\begin{array}{l}\text { Acceptance the problems and } \\
\text { responsibility } \\
\text { to solve the problems }\end{array}$ \\
\hline 2 & 0.251 & $\begin{array}{l}\text { Tend to efforts toward the } \\
\text { organization goals }\end{array}$ \\
\hline 4 & 0.098 & $\begin{array}{l}\text { Creativity in achieving group in to } \\
\text { the goals }\end{array}$ \\
\hline 5 & 0.038 & $\begin{array}{l}\text { Solving the problems and } \\
\text { conflicts }\end{array}$ \\
\hline
\end{tabular}

The above results in table 4 are shown, cooperation and partnership between all sub criteria in the third criteria (Teamwork) is more important than others, and interest to membership in groups is less important than other sub criteria.

Table 4.1: Compatibility rate for the third criteria

\begin{tabular}{cc}
\hline The number of sub criteria & CR \\
\hline 6 & 0.047 \\
\hline
\end{tabular}

According to the above results, the compatibility rate is equal 0.047 , which is less than 0.1 , then compatibility between six sub criteria in third criteria (Teamwork) has been accepted.

Table 5: Calculation significance the fourth criteria (Management)

\begin{tabular}{ccl}
\hline Ranking & Significance & \multicolumn{1}{c}{ Sub Criteria } \\
\hline 6 & 0.041 & Ability to staff training \\
1 & 0.423 & Ability to create the motivation \\
2 & 0.176 & Ability to management \\
5 & 0.089 & Creativity on work \\
4 & 0.091 & Ability to decision making \\
3 & 0.114 & Communication and Information \\
\hline
\end{tabular}

The above results in table 5 are shown, ability to create the motivation between all sub criteria in the fourth criteria (Management) is more important than others, and ability to staff training is less important than other sub criteria.

Table 5.1: Compatibility rate for the fourth criteria

\begin{tabular}{cc}
\hline The number of sub criteria & CR \\
\hline 6 & 0.047
\end{tabular}

According to the above results, the compatibility rate is equal 0.047 , which is less than 0.1 , then compatibility between six sub criteria in fourth criteria (Management) has been accepted. 
Hassan Rangriz and Hooman Pashootanizadeh

Table 6: Calculation significance the fifth criteria (c)

\begin{tabular}{|c|c|c|}
\hline Ranking & Significance & Sub criteria \\
\hline 4 & 0.079 & $\begin{array}{l}\text { Central process in the } \\
\text { development work }\end{array}$ \\
\hline $\begin{array}{l}6 \\
2 \\
3\end{array}$ & $\begin{array}{l}0.0423 \\
0.186 \\
0.184\end{array}$ & $\begin{array}{l}\text { Egoism in the development work } \\
\text { Exploit the opportunities } \\
\text { Effectiveness of work processes }\end{array}$ \\
\hline 1 & 0.425 & $\begin{array}{l}\text { Ability to decision making of work } \\
\text { processes }\end{array}$ \\
\hline 5 & 0.058 & $\begin{array}{l}\text { Ability to analysis performance } \\
\text { improvement }\end{array}$ \\
\hline
\end{tabular}

The above results in table 6 are shown, ability to decision making of work processes between all sub criteria in the fifth criteria (Procedure thinking) is more important than others, and egoism in the development work is less important than other sub criteria.

Table 6.1: Compatibility rate for the fifth criteria

\begin{tabular}{cc}
\hline The number of sub criteria & CR \\
\hline 6 & 0.059 \\
\hline
\end{tabular}

According to the above results, the compatibility rate is equal 0.059 , which is less than 0.1 , then compatibility between six sub criteria in fifth criteria (Procedure thinking) has been accepted.

Table 7: Calculation significance the sixth criteria (Systematic thinking)

\begin{tabular}{|c|c|c|}
\hline Ranking & Significance & Sub Criteria \\
\hline 1 & 0.433 & Attention to the work \\
\hline 2 & 0.276 & Ability to understand organization \\
\hline 6 & 0.03 & $\begin{array}{l}\text { General knowledge about the } \\
\text { systematic thinking barriers }\end{array}$ \\
\hline 5 & 0.038 & $\begin{array}{l}\text { General knowledge about the of } \\
\text { the dominant patterns }\end{array}$ \\
\hline 4 & 0.068 & $\begin{array}{l}\text { Knowledge of the principles } \\
\text { governing communication }\end{array}$ \\
\hline 3 & 0.141 & $\begin{array}{l}\text { Knowledge of the Violation of the } \\
\text { law }\end{array}$ \\
\hline
\end{tabular}

The above results in table 7 are shown, attention to the work between all sub criteria in the sixth criteria (Systematicthinking) is more important than others, and general knowledge about the systematic thinking barriers is less important than other sub criteria.

Table 7.1: Compatibility rate for the sixth criteria

\begin{tabular}{cc}
\hline The number of sub criteria & CR \\
\hline 6 & 0.06 \\
\hline
\end{tabular}

According to the above results, the compatibility rate is equal 0.06 , which is less than 0.1 , then compatibility between six sub criteria in sixth criteria (Systematic thinking) has been accepted.

Table 8: Calculation significance the seventh criteria (Decision Making)

\begin{tabular}{|c|c|c|}
\hline Ranking & Significance & Sub criteria \\
\hline 1 & 0.323 & $\begin{array}{l}\text { Accuracy of data and information } \\
\text { for decision making }\end{array}$ \\
\hline 3 & 0.209 & $\begin{array}{l}\text { Ability to data analysis with new } \\
\text { statistics approaches }\end{array}$ \\
\hline 2 & 0.221 & Risk appetite for decision making \\
\hline 4 & 0.128 & $\begin{array}{l}\text { Using creativity to select and } \\
\text { evaluate the correct solutions }\end{array}$ \\
\hline 5 & 0.045 & $\begin{array}{l}\text { Rapid response capability in the } \\
\text { face of crises }\end{array}$ \\
\hline 6 & 0.03 & $\begin{array}{l}\text { Ability to decision making for } \\
\text { improve the service quality }\end{array}$ \\
\hline
\end{tabular}

Sci. Technol. Arts Res. J., July-Sep 2014, 3(3): 185-190

The above results in table 8 are shown, accuracy of data and information for decision making between all sub criteria in the seventh criteria (Decision Making) is more important than others, and ability to decision making for improve the service quality is less important than other sub criteria.

Table 8.1: Compatibility rate for the seventh criteria

\begin{tabular}{cc}
\hline The number of sub criteria & CR \\
\hline 6 & 0.078 \\
\hline
\end{tabular}

According to the above results, the compatibility rate is equal 0.078 , which is less than 0.1 , then compatibility between six sub criteria in seventh criteria (Decision Making) has been accepted.

Table 9: Calculation significance the eighth criteria (Bilateral relation)

\begin{tabular}{ccl}
\hline Ranking & Significance & Sub criteria \\
\hline 2 & 0.341 & $\begin{array}{l}\text { Awareness and use of the } \\
\text { centralized banks systems }\end{array}$ \\
1 & 0.687 & $\begin{array}{l}\text { Continuous care of the } \\
\text { centralized banks systems }\end{array}$ \\
\hline
\end{tabular}

The above results in table 9 are shown, continuous care of the centralized banks systems between all sub criteria in the eighth criteria (Bilateral relation) is more important than others, and Awareness and use of the centralized banks systems is less important than other sub criteria.

Table 9.1: Compatibility rate for the eighth criteria

\begin{tabular}{cc}
\hline The number of sub criteria & CR \\
\hline 2 & 0.000 \\
\hline
\end{tabular}

According to the above results, the compatibility rate is equal 0.000 , which is less than 0.1 , then compatibility between two sub criteria in eighth criteria (Bilateral relation) has been accepted.

\section{CONCLUSIONS}

Main goal of this research was tp evaluate the employees performance who works in private and stateowned bank in Iran with use the total quality management performance evaluation model. Using this new evaluation model causes to improve the trust and job motivation in their employees who work in private and state-owned Iranian banks. On the other hand, the institutions like banks are majority economic parts in all countries, employees efficiency affect the organization performance and economic.

According the above results, privacy policy, increased knowledge and job skills, cooperation and partnership, ability to create the motivation, ability to decision making of work processes, attention to the work, accuracy of data and information for decision making and Continuous care of the centralized banks systems are more important sub criteria in each part of total quality management performance evaluation model.

\section{REFERENCES}

Ahmed, I., Sultana, I., Paul, S. K. and Azeem, A. (2013). Employee performance evaluation: a fuzzy approach. International Journal of Productivity and Performance Management 62(7): 718-734. 


\section{Hassan Rangriz and Hooman Pashootanizadeh}

Bellavance, F., Landry, S. andSchiehll, E. (2013). Procedural justice in managerial performance evaluation: Effects of subjectivity, relationship quality, and voice opportunity. The British Accounting Review 45(3): 149-166.

Carmona, S., lyer, G. andReckers, P.M.J. (2014). Performance evaluation bias: A comparative study on the role of financial fixation, similarity-to-self and likeability. Advances in Accounting, incorporating. Advances in International Accounting 30(1): 9-17.

Chen, G. andKlimoski, R.J. (2007). Training and development of human resources at work: Is the state of our science strong?. Human Resource Management Review 17(2):180-190.

Garofano, C. and Salas, E. (2005). What influences continuous employee development decisions?. Human Resource Management Review 15(4): 281-304.

Goa, F., Li, M. andNakamori, Y. (2002). System thinking on knowledge and its management: systems methodology for knowledge management. Journal of knowledge management 6(1): 7-17.

Hung, S. W., He, D. S. and Lu, W. M. (2014).Evaluating the dynamic performances of business groups from the carryover perspective: A case study of Taiwan's semiconductor industry. Omega 46: 1-10.
Sci. Technol. Arts Res. J., July-Sep 2014, 3(3): 185-190

Kadan, O. and Liu, F. (2014).Performance evaluation with high moments and disaster risk. Journal of Financial Economics 113(1): 131-155.

Ladd, B. S. and Marshall, V. (2004). Participation in decision making: a matter of context?. The Leadership and Organization Development Journal 25(8): 646-662.

Ngacho, C., Das, D. (2014). A performance evaluation framework of development projects: An empirical study of Constituency Development Fund (CDF) construction projects in Kenya. International Journal of Project Management 32(3): 492-507.

Penalvo, F.J.G. and Conde, M. (2014).Using informal learning for business decision making and knowledge management. Journal of Business Research 67(5): 686691.

Saad, G.H. (2001). Strategic performance evaluation: descriptive and prescriptive analysis. Industrial Management and Data System 101(8): 390-399.

Slaughter, J.E., Bagger, J. and Li, A. (2006).Context effects on group-based employee selection decisions. Organizational Behavior and Human Decision Processes 100(1): 47-59.

Wu, H.Y., Lin, Y.K. and Chang, C.H., (2011).Performance evaluation of extension education centers in universities based on the balanced scorecard. Evaluation and Program Planning 34(1): 37-50. 